\title{
Lumen
}

Selected Proceedings from the Canadian Society for Eighteenth-Century Studies

\section{Human Nature and Truth: Hume and Pascal}

\section{Terence Penelhum}

Volume 12, 1993

URI : https://id.erudit.org/iderudit/1012578ar

DOI : https://doi.org/10.7202/1012578ar

Aller au sommaire du numéro

Éditeur(s)

Canadian Society for Eighteenth-Century Studies / Société canadienne d'étude du dix-huitième siècle

ISSN

1209-3696 (imprimé)

1927-8284 (numérique)

Découvrir la revue

Citer cet article

Penelhum, T. (1993). Human Nature and Truth: Hume and Pascal. Lumen, 12, 45-64. https://doi.org/10.7202/1012578ar

Copyright (c) Canadian Society for Eighteenth-Century Studies / Sociéte canadienne d'étude du dix-huitième siècle, 1993
Ce document est protégé par la loi sur le droit d'auteur. L'utilisation des services d'Érudit (y compris la reproduction) est assujettie à sa politique d'utilisation que vous pouvez consulter en ligne.

https://apropos.erudit.org/fr/usagers/politique-dutilisation/ 


\section{Human Nature and Truth: Hume and Pascal}

It may seem strange to combine the names of two such radically opposite thinkers as Blaise Pascal and David Hume. But I shall suggest that when we juxtapose some of the fundamental aspects of their thought, the result is instructive in several ways. First, though least in real importance, I think it becomes possible to make some conjectures about direct influence from Pascal in the seventeenth century to Hume in the eighteenth. (I say 'conjectures' for several reasons. One of them is that Hume is a master of non-citation when it suits him, and his overt references to Pascal do not suggest direct influences.) Second, since we are dealing here with two figures of the very highest genius, the one the greatest of all Christian apologists, and the other the most considerable of all the philosophical secularisers of modern times, it is instructive to find them offering totally opposed inferences and value-judgments, indeed totally opposed life choices, on the basis of remarkably similar understandings of the inner workings of the human spirit. There is no doubt at all that they would have disliked each other extremely had they been contemporaries; but it is equally beyond reasonable doubt that they share many perceptions of the human condition, even though they offer wholly contrary prescriptions for human ills. Between them they represent two poles in the debate over the nature of humankind in modern times. Between them they define modernity.

The third way in which I think we can derive instruction from the juxtaposition of the thought of these two men follows from the second. Although each is of the greatest importance in the historical understanding of the seventeenth and eighteenth centuries, each has a stature that obviously transcends this. The debate between them is one that still continues; and I shall suggest that, whichever side of the debate one is inclined to favour, the comparison between them prompts disturbing reflections about the nature of this debate itself. I shall conclude by airing a few of these.

A few brief personal comments. I come to this theme as a philosopher who read Hume in his very first year as a student of the subject, as most philosophy students do, and who later came to study his system in some 
detail, and to take a small part in the very vital debates about the nature of that system that are still in progress now. I claim no parallel specialist knowledge of Pascal. I came to study him in the course of my reflections on questions in the philosophy of religion, and also in personal reflections on religious issues; any assertions I may make in what follows about what he says are those of an uninformed enquirer who has been stimulated by a writer of unique psychological and literary power to try to learn something about his times and his objectives from the works of other scholars.

In summary: I shall suggest that Hume's philosophical system contains within it careful and elaborate responses to many of Pascal's fundamental claims, responses which are only possible because the two men hold many detailed theses in common. Before arguing this, I first look at Hume's direct references to Pascal, such as they are, and say something about how far Pascal's thought was available to the world of letters in Hume's day.

Hume comments on Pascal in only two places. The first is in a lengthy footnote to his famous Section 'Of Miracles' in the Enquiry Concerning Human Understanding. While the primary target of Hume's argument in that Section is the belief in the miracle-stories of the New Testament, especially the Resurrection narratives, he also takes time to comment, adversely of course, on alleged miracles of his own time. The note is mostly concerned with miracles associated with the tomb of the Jansenist deacon Pâris; but the concluding paragraph is about 'a miracle, wrought on the niece of the famous Pascal, whose sanctity of life, as well as extraordinary capacity, is well known. ${ }^{11}$ This event, dated 1656, was the miracle of the Holy Thorn, in which Pascal's niece, Marguerite Périer, appeared to have been cured of a lachrymal tumour when it was touched by a relic said to be a fragment of the original Crown of Thorns. This cure helped to cement Pascal's loyalty to the Jansenists of Port-Royal, where it took place. As we would expect, Hume treats the story with derision. ${ }^{2}$ He probably singles it out in order to strike a blow against the views about miracle testimony found in the Port-Royal Logic. ${ }^{3}$ Pascal figures in his comments as an example of a person of exceptional intelligence who is nevertheless convinced by a phenomenon Hume takes it for granted his mostly-Protestant readers will dismiss.

The second mention of Pascal is lengthier, and more polite, but still very negative. We find it in a 'Dialogue' that Hume appends to his Enquiry Concerning the Principles of Morals. The theme of this dialogue is 
the great variation in moral customs throughout the world, which leads people in one society to commend as virtuous conduct that would be condemned as vicious in other societies. The imaginary interlocutor who parades a variety of examples of this moral diversity is called Palamedes. Hume tells Palamedes that in spite of these variations, every human quality that is commended as virtuous is one that is judged to be either useful or agreeable, either to the person who has it, or to others: in a word, to have utility. Disagreements are all about what qualities are useful or agreeable; everyone agrees that it is usefulness and agreeableness that should be praised and cultivated. But Palamedes has a problem: this may well be true for the 'maxims of ordinary life and conduct,' but what about 'artificial lives and manners'? He explains that he is thinking of those whose lives are determined primarily by the influence of philosophical theory, or of religion. Philosophical theory led to eccentric moral attitudes in the ancient world; in modern times its place has been taken by religion, since philosophy has become a minority pastime. His ancient example of moral eccentricity is Diogenes; his modern example is Pascal, whom he chooses, he says, because he was a 'man of parts and genius... and perhaps, too, a man of virtue, had he allowed his virtuous inclinations to have exerted and displayed themselves.' Both these men showed contempt for common practices and values, 'yet both of them have met with general admiration in their different ages, and have been proposed as models of imitation. Where then,' he continues, 'is the universal standard of morals, which you talk of?' Hume's cryptic answer to this question is that in these cases 'the natural principles of their mind play not with the same regularity, as if left to themselves, free from the illusions of religious superstition or philosophical enthusiasm. ${ }^{4}$ While it seems clear enough that Hume is less severe on Diogenes' philosophically-motivated oddities than on Pascal's religiously motivated ones, we must not forget that one of the aspects of religion in his own time that most angered him was the fact that it had absorbed so much philosophy into it. ${ }^{5}$ It is in part the very admixture of philosophy in Pascal's religious apologetic that makes it a formidable target for him. In the dialogue we are examining, however, the eccentricities he finds in Pascal are all of the superstitious and life-denying kind. Pascal, he says, was determined never to forget his 'wants and infirmities,' showed a humility and 'hatred of himself,' practiced austerities 'merely for their own sake,' refused innocent pleasures 'even in private,' and tried to cultivate an indifference even to those closest to him, 'and to love and speak well of his enemies.' He sums up Pascal's conduct by saying, 'The most ridiculous superstitions directed Pascal's faith and practice; and an extreme contempt of this life, in comparison of the future, was the chief foundation of his conduct' (EM 343). 
While these comments are not perhaps derisory, they are certainly as strongly negative as the judgments implied in Hume's remarks about the Holy Thorn. Certainly nothing here suggests Hume could have been influenced by the person he is describing, and Pascal's life and behaviour are used as a source of cautionary tales. So Hume seems to be following the estimate of Pascal that was common in his day, and that had been expressed most famously by Voltaire in his Lettres Philosophiques:

Il me paraît qu'en général l'esprit dans lequel M. Pascal écrivit ces Pensées était de montrer l'homme dans un jour odieux. Il s'acharne à nous peindre tous méchants et malheureux. Il écrit contre la nature humaine à peu près comme il écrivait contre les Jésuites. ..... J'ose prendre le parti de l'humanité contre ce misanthrope sublime. ${ }^{6}$

On this view, Pascal's estimate of himself, and of others, was that of a scientific genius led astray by superstition into morbid estimates of our condition that could only be excused by the fact of his sickness: 'Hélas encore! hélas! Pascal, on voit bien que vous êtes malade' (Lettres philosophiques 286). ${ }^{7}$

So if we confine our attention to the two passages where Hume considers Pascal explicitly, it is tempting to suppose that he merely thinks of him as Voltaire does. ${ }^{8}$ His comments could well have been based, as far as this evidence goes, either on Voltaire's very superficial criticisms or on the information and comments in Bayle's article on Pascal in his Dictionary. But I think there is reason to suppose Hume had read and pondered Pascal for himself.

\section{II}

We can, in the first instance, find strong Pascal-like overtones in one of the most important and revealing parts of Hume's major work, the Treatise of Human Nature. I refer to the concluding Section of the first book, where Hume describes the 'philosophical melancholy and delerium' into which he is thrown by his sceptical reflections. The popular image of Hume as a corpulent and rather frivolous thinker who does not take philosophical questions with their proper seriousness is as wide of the mark as the popular image of Pascal as an other-worldly hater of society. Just as the latter makes us overlook how much Pascal was involved in the world of science and letters, and eagerly demanded his proper place in it, in the period before his second conversion, so the popular picture of Hume makes us overlook the fact that his lightness 
of manner and emphasis on the limits of philosophy was a stance assumed deliberately by a person of somewhat depressive temperament, who had been brought to the edge of breakdown by his philosophical enquiries. ${ }^{9}$ In the concluding Section of Book I of the Treatise, Hume expresses the anxiety at the heart of philosophical questioning in language that Pascal may have taught him:

I am first affrighted and confounded with that forelorn solitude, in which I am plac'd in my philosophy, and fancy myself some strange uncouth monster, who not being able to mingle and unite in society, has been expell'd all human commerce, and left utterly abandon'd and disconsolate. Fain wou'd I run into the crowd for shelter and warmth; but cannot prevail with myself to mix with such deformity. I call upon others to join me, in order to make a company apart; but no one will hearken to me. Every one keeps at a distance, and dreads that storm, which beats upon me from every side. ${ }^{10}$

Again:

The intense view of these manifold contradictions and imperfections in human reason has so wrought upon me, and heated my brain, that I am ready to reject all belief and reasoning, and can look upon no opinion even as more probable or likely than another. Where am I, or what? From what causes do I derive my existence, and to what condition shall I return? Whose favour shall I court, and whose anger must I dread? What beings surround me? and on whom have I any influence, or who have any influence on me? I am confounded with all these questions, and begin to fancy myself in the most deplorable condition imaginable, inviron'd with the deepest darkness, and utterly depriv'd of the use of every member and faculty. (Treatise, 1.4.7, 269.)

To the modern reader of Pascal these make one think of the following very famous passage:

Quand je considère la petite durée de ma vie absorbée dans l'éternité précédente et suivante-memoria hospitis unius diei praeteriuntis-le petit espace que je remplis et même que je vois abîmé dans l'infinie immensitée des espaces que j'ignore et que m'ignorent, je m'effraye et m'étonne de me voir ici plutôt que là, car il n'y a point pourquoi ici plutôt que là, pourquoi à présent plutôt que lors. Qui m'y a mis? Par l'ordre et la conduite de qui ce lieu et ce temps a[-t-]il été destiné à moi? ${ }^{11}$ 
This in turn makes us all recall the briefer and even more famous, 'Le silence éternel de ces espaces infinis m'effraie' $(201 / 206)$.

So if we can concede that there is more philosophical bewilderment in Pascal's cosmic terrors, and more existential angst in Hume's epistemological perplexities, than the standard history-books tell us, it is not fanciful to think that the later thinker is echoing the earlier. With this is mind, a more specific echo can then strike us with some force.

Both writers have occasion to offer critical estimates of the Hellenistic schools of Stoicism and Scepticism. We find this fragment in Pascal:

\section{Stoïques.}

Ils concluent qu'on peut toujours ce qu'on peut quelquefois et que puisque le désir de la gloire fait bien faire à ceux qu'il possède quelque chose, les autres le pourront bien aussi.(146/350) $)^{12}$

In Part I of Hume's Dialogues concerning Natural Religion we find the following comment:

In this view, there appears a great resemblance between sects of the Stoics and the Pyrrhonians, though perpetual antagonists. And both of them seem founded on this erroneous maxim, that what a man can perform sometimes, and in some dispositions, he can perform always, and in every disposition. ${ }^{13}$

Having opened up the possibility of making conjectures about influence, however, I must now refer to an obvious problem that faces any theory about Pascal's influence in the eighteenth century. His projected Apology for the Christian Religion was far from completion at the time of his death, and what we have in the Pensées are fragments assembled by a succession of editors. While the most recent presentations of his work may order these fragments in a way that approximates to Pascal's own intentions, in Hume's time they were available only in the version edited by some of his friends at Port-Royal, and published in 1670 and 1678. This version differs markedly from the more complete and authentic ones now available to us. So a thought that seems to find a parallel in the work of a writer in the century after Pascal's death is less likely to have exerted a direct influence if the fragment or fragments containing it did not appear in the Port-Royal edition. I have already supplied, deliberately, examples to illustrate the problem. The two famous fragments I quoted to show the metaphysical component in Pascal's expressions of human anxiety did not appear in any edition available to Hume. The comment about the Stoics, however, did appear there. So although Hume's remark about the Stoics and Pyrrhonians does make it likely 
that he read the Port-Royal edition, and did not depend for his understanding of Pascal on secondary writings (of which there were, of course, a great many ) ${ }_{1}^{14}$ if his reflections on the philosophical predicament are in any way allusive to Pascal, they cannot be allusions to the fragments of which they most naturally remind $u s$.

For reasons that were religious, political, and philosophical together, the Port-Royal editors arranged Pascal's fragments in a thematic order that was quite different from the order that Pascal himself had intended to follow, and which he had himself described to them. ${ }^{15}$ Not only were they rearranged, and in the case of some of the longer and more finished ones shortened and even split up, but about half of those now in modern editions were omitted altogether. There appears to have been a deliberate policy of suppressing themes that are essential to an understanding of Pascal's intentions. His hostility to Descartes, with whom the editors sympathised quite strongly, was not allowed to show. His insistence on the valuelessness of attempting to prove the existence of God (a standard part of apologetics since Aquinas) was editorially excised. So was his qualified but quite emphatic endorsement of Pyrrhonian Scepticism, which includes a fragment that begins unambiguously with the assertion 'Le pyrrhonisme est le vrai' (691/432). This, too, is a vital phase in his apologetic strategy. (The famous Wager argument, for example, presupposes it.) The result of these heavy-handed editorial intrusions is a much-censored edition of Pascal's work, which is presented in an over-simplified and domesticated form that makes it harder to recognise how far he intended to depart from traditional apologetics.

But although this is important, its importance should not be exaggerated. Writing as powerful as Pascal's can still make its impact in spite of editorial obfuscations, and it does so many times over. We should also bear in mind that the Port-Royal editors put in a preface by Étienne Périer that included an account of the occasion when Pascal described the plan of his apologetic project to his friends; so although their editorial plan departs in major ways from that plan, this fact, however reprehensible it is, is not concealed, and it is possible for a reader to interpret what the edition contains in the light of Pascal's reported purposes. Furthermore, another important document, the Entretien avec M. de Saci, was published in 1728, and in this document Pascal comments at length on Epictetus and Montaigne, who represent Stoicism and Pyrrhonism for him; what is available here compensates to a modest degree for some of the philosophically important omissions in the Port-Royal text.

I think we can assume that although Hume would certainly not have been one of Pascal's more sympathetic readers, he would, nevertheless, have been one of his more discerning ones. If, therefore, we find important elements in his thought that either resemble distinctive themes in 
Pascal, or are manifest contrasts to them, I suggest this will be deliberate and not accidental. I shall be concerned here with two areas in which we do find this. The first is their understanding of human nature, and in particular the ways in which its non-intellectual elements contribute to the formation of our beliefs. The second, as we would expect, is their understanding of the nature of religious faith. In the first we find instructive similarities, and in the second instructive and deliberate contrast.

III

I cannot enter into detailed discussion of Pascal's apologetic strategy; but it is, I think, uncontroversial now that the most important innovation in this strategy was his intention to begin with a depiction of human nature rather than a philosophical attempt to prove the reality of God. The portrayal of human nature that he planned, and partially executed, was one that would have the purpose of bringing about the reader's acknowledgment of the paradoxes of his or her own condition. The apologetic was designed to move the reader toward conversion, not mere philosophical enlightenment, and the self-knowledge that Pascal, in true Socratic manner, sought to induce, was a self-knowledge that would lead the reader to listen to God, not engage in philosophical analysis (see $131 / 434)$. This portrayal of human nature emphasises both its wretchedness and its grandeur. (The appearance of misanthropy that so angered Voltaire derived in part at least from the fact that the editors, as true Augustinians, emphasised in their selections the wretchedness at the expense of the grandeur, giving the whole document an air of conventional gloom.) Pascal's vision combines the wretchedness and the grandeur in a paradoxical manner designed to cry out for special explanation and special cure: the explanation, of course, being the doctrine of the Fall and the cure being redemption through Christ. The uneasy mixture of wretchedness and grandeur, Pascal tells us, has led thinkers like the Stoics to attempt to gain redemption through the use of reason. It has been the role of the Sceptics, such as the classical Pyrrhonists and their modern counterparts like Montaigne, to turn reason on itself and show that it is incapable of fulfilling this role. The role can only be fulfilled by faith; and Pascal tries to turn the reader from a recognition of his divided and anxious condition toward faith by urging him to take account of the signs of God's presence and his wish to redeem us that are available to us all, especially in the Scriptures. These signs, though always present, are hidden from those who are unwilling to acknowledge their need for them, and choose instead to seek distraction from 
their finitude and their sinfulness. For those willing to listen to God, the Scriptures are full of the signs of his redemption in Christ. Much of the latter part of the Apology was to have been devoted to a scrutiny of the Scriptures that showed these signs to those willing to seek for them. The editors obscured the strategy that Pascal had himself outlined to them by placing many of the passages dealing with scriptural interpretation toward the beginning of their edition, thus ignoring the important fact that the reader was to have been urged to see the signs the scriptures contained only after being brought to seek a cure for his condition, and not before.

The most important feature of Pascal's strategy, then, was the fact that it proceeded from the analysis of the human condition, through an attack on the attempt to cure that condition by philosophical reasoning, an attack that involved Pascal in accepting the philosophical correctness of Scepticism, to an examination of the signs of God's proffered redemption in the New Testament. It was a strategy that self-consciously dispensed with the attempt to prove the existence of God by philosophical means. For Pascal thinks such an attempt is spiritually inappropriate. I shall return to the reasons he gives for this judgment (reasons which are excised from the Port-Royal edition) at a later stage. The fact that he makes it, however, entitles us to place him firmly in the Fideist tradition of apologetic, and to see him as the most important ancestor of Kierkegaard, whom he anticipates in many ways. ${ }^{16}$

But Kierkegaard is not the only thinker he anticipates. For one might well state the anti-rationalist thrust of Pascal's apologetic strategy by saying that in his view, 'To be a philosophical sceptic is the first and most essential step towards being a sound, believing Christian.' That, as anyone familiar with him will immediately have recognised, is a quotation from Hume (Dialogues, 228). It is high time we returned to him.

While the differences between Hume's intentions and Pascal's could not be greater, they are precisely the sorts of difference that generate important parallels and similarities. I have already said that Pascal's evocation of human anxiety and finitude has a clear philosophical strand in it, and that Hume is a thinker who was not merely puzzled by philosophical problems but anxious in the face of their non-resolution. I will now go further, and say that just as the Sceptics of antiquity offered their arguments against the cosmic claims of Epicureans and Stoics as a cure for anxiety and not merely for intellectual display, so Hume is, like Pascal, offering his serious reader more than a journey through intellec- 
tual excitements. He is offering a saving way of life. It is, certainly, a self-consciously restricted, and to some no doubt enervating, way of life; but it is equally a response to the anxieties of the human condition. It is a deliberately secularising response, because Hume sees religion as a major source of anxiety, not a cure for it. But it represents a systematic attempt to use an understanding of human nature as a basis for a way of life that will free us from those avoidable ills that are due to misunderstandings of it. Hume is in the Hellenistic, and therefore in the Socratic, tradition; and it is of the essence of his philosophical system (and he does not fail to have one merely because philosophy students are always encouraged to read him in anthologised bits) that it is in the secularised and scientific study of what our nature is really like that we can find the right ways of escaping human anxiety. It is also of the essence of that system that philosophy, like religion, has to have its proper place determined by that study if it is not to be a source of anxiety and social distress on its own account.

Given these likenesses between what Pascal and Hume are about, and their parallel inclinations toward philosophical scepticism, it is in no way a surprise that they should say remarkably similar things about the way the non-intellectual components in our natures determine the formation of our beliefs, and the structures of our social relationships. It is also, of course, to be expected that although they frequently tell the same story about human nature and its workings, their evaluation of the story they tell is almost always opposite.

It is high time for some illustrations. ${ }^{17}$ The first general theme that both thinkers emphasise is the importance of the non-intellectual forces in human nature in the formation of our beliefs. Both lay great stress on two such forces: one is custom, and the other is imagination.

Pascal's dominant image for the role of custom (coutume, habitude) in our natures is the machine. Man is, as Descartes said, a machine as well as an intelligence; but in a way that Descartes ignored, this means that the human mind too is mechanical, that is, habitual, in its workings. Our beliefs are largely determined by this. To philosophers, the most famous passage in which Pascal makes use of this insight is near the close of the Wager argument, where the doubter is persuaded to induce belief in himself by becoming habituated through religious observances: 'Naturellement même cela vous fera croire et vous abêtira.' The fragment is partially reproduced in the Port-Royal text, but this thoroughly unCartesian sentence is omitted (418/233, Port-Royal XXI.2). There are, however, many other key fragments that emphasise the importance of custom. In one of the most philosophically interesting to find its way into the Port-Royal text, Pascal contrasts the importance of custom in producing beliefs with the relative unimportance of proofs: who ever 
proved, he says, that it will dawn tomorrow, or that we will die? and what is more widely believed than these things? (821/252, Port-Royal VII.3). ${ }^{18}$ The anticipation of Hume could hardly be more direct. For everyone who knows about Hume at all knows that he tells us it is custom, and not reason, that assures us the sun will rise tomorrow. And just as Hume's conception of custom is far wider than that of internal habit, and embraces the social conventions on which the artificial virtues, particularly justice, depend; so Pascal attributes to custom in this wide sense the power that social institutions have upon us: 'La justice est ce qui est établi; et ainsi toutes nos lois établies seront nécessairement tenues pour justes sans être examinées, puisqu'elles sont établies' $(645 / 312)$.

As with custom, so with the intimately allied faculty of imagination. For both writers, the imagination is the major force that determines the character of our life-world. Here, as elsewhere, it is only Hume who is systematic; for him the fundamental principle that determines the workings of the mind is the principle of association; this principle governs the imagination, that is, the faculty that creates images and supplies our experience with what direct perception and reasoning cannot supply. ${ }^{19}$ In doing this, Hume tells us, the imagination will frequently beguile the reason, and will make us lazily acquiesce in many opinions it is convenient for us to believe, but for which the Sceptic can readily demonstrate we do not have evidence. (Among these beliefs are the confidence in the continuing existence of objects we no longer see or touch, or the universal regularity of the natural world.)

Pascal also paints the imagination as a power that beguiles us. It is a puissance trompeuse, a deceptive power: one that enables us, very particularly, to deceive ourselves. It is true that sometimes its power will overcome our inclinations and fill us with irrational fears (one thinks here of his famous example of the great philosopher on a plank over a precipice, who knows that the plank is quite wide enough to save him, but is still struck with terror by his imagination [44/82]); but more commonly it beguiles us in ways we want-as when magistrates and physicians wear pompous garments in order to stimulate the imagination of their public and stifle their critical judgment.

A comparison between the relevant texts makes it instantly obvious that although Pascal often accords both custom and imagination the same functions that Hume does, his evaluation of those functions is far more negative. To Pascal, the fact that custom and imagination can entrench beliefs that philosophical criticism can show to have no rational foundation is a sign of human depravity and self-deception. But Hume tells the story of their powers in a wholly different tone of voice. For him, the fact that we come to believe what we do through habit and conven- 
tion is a merciful dispensation, for without it we would be sunk in practical paralysis. The fact that we are not rigorous analysts most of the time is a Darwinian provision, essential for our survival. He even says in one famous place that 'Carelessness and inattention alone can afford us any remedy. For this reason I rely entirely upon them' (Treatise 1.4.2, 218). This remark usually raises a smile; but Hume means it. Nevertheless, the story he has told when he makes it, the story of how we come to believe in the reality of the physical world outside us, is a story full of ascriptions of laziness and confusion that Pascal would have found congenial.

So Pascal and Hume are at one in regarding our beliefs as being, in Hume's language, 'more properly an act of the sensitive, than of the cogitative part of our natures' (Treatise 1.4.1, 183 ). Pascal would have said they are the work of the heart, rather than of the reason. They are even more clearly at one on the way in which, as they see it, our natures, so described, protect us against the effects of Sceptical argument. Both Pascal and Hume say that the arguments of the Pyrrhonian Sceptics are unanswerable: that is, no philosopher has been able to refute them. But both also say, quite explicitly, that the non-intellectual elements in our natures protect us against the despair and the inaction that would otherwise follow from this. In Pascal's case we find an interesting complication: while maintaining that our natures ensure that there can be no such thing as a thoroughly Pyrrhonian person in practice, he reserves his most extended and vitriolic attacks for those who seem, at least, to manage to live out the easy-going acceptance of our intellectual limits that the classical Pyrrhonists, such as Sextus Empiricus, proclaimed as the natural result of abandoning the search for knowledge. This seems to involve him in condemning as wickedly frivolous an attitude that he seems also to say our nature makes impossible for us. If it is impossible, why go on so much about how monstrous it is to adopt it? I think the answer is that Pascal thinks there are only some spheres in which our natures supply us with the beliefs we need to avoid sceptical anxiety: roughly, those of common sense and science. The apparent insouciance with which professed sceptics proclaim their doubts about deeper, cosmic matters is only assumed and not real. We can see this in the way in which they, like the rest of us, seek to distract themselves from the fact of human finitude and weakness by vanities and diversions. Few things in the Pensées are better known than the passages in which Pascal tries to expose the self-deception at the heart of play and recreation, which he sees as primarily a process of filling the soul with distracting rubbish that hides the self's emptiness from it. The off-hand lightness of the Sceptic's tone is one such game, designed, as all games are, to deceive all who take part in it. ${ }^{20}$ 
Hume's attitude to Scepticism is in all key respects the same. He thinks the doubts of the Pyrrhonian cannot be answered by argument, in spite of the repeated efforts of philosophers. But no one is affected in practice by this. The Sceptic's doubts are 'vain' or impotent. They admit of no answer and produce no conviction. ${ }^{21}$ The scientific study of the imagination and its workings shows why: it is because we are beings who are instinctively programmed to believe. But although we are instinctively programmed to believe, and would be driven to insanity by the Sceptic's arguments if this were not so, the fact that there is no refutation of these arguments is disturbing to the unhappy few who have a predilection for philosophical enquiry. Hume himself is such a person, and after a solid dose of sceptical philosophy he fancies himself, he says, a strange uncouth monster, racked by anxiety. This state is unnatural, but it is real enough while it lasts. Hume joins Pascal in thinking that Sceptical doubts do not lead to the peace of mind that the Greek Sceptics said, but to anxiety, unless something can rescue us. What can? Hume's answer is: distraction; play. 'I dine, I play a game of back-gammon, I converse, and am merry with my friends; and when after three or four hours' amusement, I wou'd return to these speculations, they appear so cold, and strain'd, and ridiculous, that I cannot find it in my heart to enter into them any farther' (Treatise 1.4.7, 269). Hume's cure for the ills of sceptical doubt involve him in leaning on those very resources of feeling, instinct and social life that Pascal has seen as puissances trompeuses. There are other aids too: there are the intellectual distractions that can come from directing one's rational faculties away from those worrying cosmic questions that are beyond us, and on to history, or science. And there are the protections that come from fighting those superstitions that generate their own brands of fear and anxiety, and weaken our social resources by turning us away from society and its nourishments for the spirit. It is Hume's turn to be vitriolic when he comments on 'celibacy, fasting, penance, mortification, self-denial, humility, silence, solitude, and the whole train of monkish virtues.' These, if we pursue them, prevent us from shoring one another up against the darts of anxiety and superstition. 'A gloomy, hair-brained enthusiast, after his death, may have a place in the calendar; but will scarcely ever be admitted, when alive, into intimacy and society, except by those who are as delirious and dismal as himself' (EM 270).

I have argued so far that the opinions of Pascal and Hume on the relation between human nature and truth are largely mirror-images of one another. Hume's naturalism is often said by scholars to be developed in systematic opposition to rationalist interpretations of the human mind. This is indeed true. But Pascal's teachings are developed in opposition to rationalism also, in spite of his well-known remarks about 
the dignity of reason. They both give reason a role in human life; but each maintains that that role is more restricted than the rationalists from Plato to Descartes have maintained. I think we can understand Hume's naturalism better if we see it as being intended, in addition, as a systematic antidote to the sort of fideism that Pascal wanted to substitute for rationalism. To try to confirm this judgment, I shall conclude with some comments on how Hume responds to Pascal's philosophy of religion.

I must begin this with an extract from one of the more substantial fragments of the Pensées —one that was included in the Port-Royal text:

De plus que personne n'a d'assurance, hors de la foi-s'il veille ou s'il dort, vu que durant le sommeil on croit veiller aussi fermement que nous faisons. [Moreover, no one can be sure, apart from faith, whether he is asleep or waking, because when we are asleep we are just as firmly convinced we are awake as we are now.] (131/434, Port-Royal XXI.7). ${ }^{22}$

This remark has an obvious target-the Descartes of the first Meditation. Pascal is insisting that sceptical doubts, such as Descartes' suggestion that we might, at any given time, be dreaming when we think we are awake, cannot be answered by reasoning as Descartes believed. The assurance that we need is supplied not by reason, but by the heart-by the instincts, as Hume was to say later. We have already seen this major area of agreement between them. But Pascal takes a further step that Hume could not take. To Pascal the heart that gives us this reassurance is intended by God to open itself to him. For, he says, it is the heart, not the reason, that perceives God; indeed that is what faith is: God perceived by the heart, not by the reason $(424 / 278)$. Therefore the obstacles to faith are not intellectual; they lie in our passions, and it is these that we must tame before the signs of God's redemption can enter the heart as he intends.

So to Pascal common sense conviction about our own immediate environment, and faith in God, are epistemologically continuous. Both come, if they come at all, from the heart, not the intellect. The fact that so many have the one, but not the other, is due not to anyone's intellectual limitations (for the intellect supplies neither), but to corruption and to pride. Therefore Pascal says that our common sense convictions are as much a matter of faith as faith is. 
Hume, of course, rejects this. But how can he reject it? ${ }^{23}$ He tells us with approval that the resources of instinct supply us with the beliefs we need at the level of secular common sense, in spite of the limitations of our reason; but he seems to think that the inability of reason to generate or justify the claims of religious faith is a good reason for not accepting those claims. Why should he accept the one and not the other?

Hume has several answers to this challenge, as one would expect. What is crucial for the understanding of his system, however, is that he sees the need to produce them and is occupied in doing so throughout his philosophical career. His answers are meticulously connected, and together they constitute a systematic naturalistic response to Pascal's apologetic. I want to outline it; to do this I must comment, very briefly, on three of his anti-religious writings.

I turn first to his short treatise, The Natural History of Religion. In this rather neglected work, Hume begins by separating out the question of the justification of religious beliefs from the question of their origins in human nature. He then addresses the second question, and tells a story about why it is that people believe in gods, and come to believe in one supreme God-for he is convinced that religion begins as primitive polytheism and evolves into high theism only much later. The story he tells is a story of mankind haunted by fears and anxieties in the face of natural dangers and calamities. As these calamities assault them, they reach for the only sort of explanations they can invent. They ascribe the disasters that befall them to the intervention of personal powers, and fill their imaginary world with spiritual agents that intervene in nature and have to be appeased by worship and flattery. Much later, this polytheistic world is further darkened by the rivalries that result when the devotees of one such god seek his approval by insisting on his merits to such an extent that they reject the claims of all the others and try to retain his favour by extremes of flattery. The inner logic of worship thus creates the omnipotent and all-knowing deity who cannot be admitted to have any moral failings yet knows all our failings intimately and demands total obedience. Hume insists that, given these origins, the devotional stance that worshippers have toward such a God does not embody the certitude and consolation that Pascal proclaims as the fruit of faith, but is a condition that is insincere, ambivalent, and chronically anxious-a condition very like the state Pascal had said the human soul is in without the consolation of the presence of God. So he offers a naturalistic account of the power that the idea of God has. And it is a story about the power of the God of Abraham, Isaac and Jacob, not a story about the God of the philosophers from whom Pascal is so anxious to distinguish Him.

I turn now to the most famous of Hume's anti-religious writings, 'Of Miracles' (EU, Sec. X). Hume's argument here, which I shall not repeat, 
is designed to show that the supposedly revelatory signs of God to which Pascal urges us to be open are historically dubious, and only acceptable if we suspend the very dependence on custom and habit that is the sole antidote to Scepticism at the common sense level. His special hostile interest in the miracle story of Port Royal is not an accident.

I turn, thirdly, to Hume's most important study of religion, the Dialogues concerning Natural Religion. It deals, of course, with the attempt to prove the existence of God by reason. Pascal explicitly rejects this way of persuading his readers toward faith. He gives more than one reason for this rejection, and I am unsure how far the reasons he gives are fully consistent with each other. But his most telling comment is his assertion that such philosophical arguments can lead only to deism, which he says is almost as remote from the Christian religion as atheism is $(449 / 556)$. The God to whom Pascal wishes to bring us is a God who fills the heart and soul; he intervenes in history with repeated acts of grace. The God of the deists did no such thing. ${ }^{24}$ Now while Hume shares a low estimate of the attempts to prove the existence of God, and indeed many think he has destroyed them, he appears near the very end of the Dialogues, in passages that are the despair of commentators, to espouse, himself, a vague and minimal form of deism, and even to commend it as 'true religion.' His private opinions, artfully concealed beneath the dialogue form, are hard to determine; but he seems to encourage, or at least to acquiesce in, the polite, philosophical apologetic that issues in the totally formal and unreligious acknowledgment of a wholly non-interventionist deity. This is a form of so-called religion that will bolster, and not disturb, the way of life that human beings in polite lettered society have developed for themselves. Such a God, unlike Pascal's, is hidden only in the sense that his presence or absence would make no difference at all to experience. While we cannot be sure how far Hume's protagonists in the Dialogues speak for him at the close, it seems clear, in my judgment, that this is largely because what is left at issue between them by then is not very important. Pascal had eschewed the attempt to prove the existence of God because such a proof was not worth providing and gives the soul no religious nourishment. For this very reason, Hume does not think such a proof is worth fighting. For the God of the philosophers never intervenes.

When faced with the silence and ambiguity of nature, Pascal was torn and wrote, in a passage to which Hume had access, about the way in which his spirit was divided between what seemed to be signs that God was present and what seemed to be a vision of a world without God (429/229, Port-Royal VIII.1). By the end of the Dialogues , Hume seems willing to concede a cause, or causes, of cosmic order that probably bears some remote analogy to human intelligence and has 'neither goodness 
nor malice. ${ }^{25}$ He describes his acquiescence as a 'plain, philosophical assent.' I have my doubts whether in private Hume assents even to this vague deistic position, but I am sure that if he does it is precisely because it is a position that is as far from Christian faith as Pascal says it is. And it is possible for Hume's reader to come to rest in this bland and religiously empty view because Hume has given an account of his competing theistic impulses that will make him distrust them, and has undermined his confidence in the reality of those revelatory events where he might be inclined to think God can be found.

The important fragment in which Pascal rejects the apologetic route of the theistic proofs is not in the Port-Royal edition, whose Cartesian editors would have found it distasteful. But even if Hume could not otherwise have inferred Pascal's estimate of the value of the theistic arguments, it is an estimate he was well able to reach on his own account. And having done so, he was able to commend the product of such argument for the very reason Pascal had given for condemning it.

Scholars have guessed that the personages in Hume's Dialogues can be identified with some of his predecessors, such as Samuel Clarke (Demea), Joseph Butler (Cleanthes) and Pierre Bayle (Philo). ${ }^{26}$ Perhaps. But I do not doubt, myself, that although Hume took the measure of all these thinkers, he also saw himself as responding to someone who towered above them intellectually as well as religiously, someone whose challenge he thought it much more important to meet.

I have tried to suggest that the two great men whose work I have been comparing agree in far more than is usually recognised and that Hume is trying, however much or little we can trace his ideas to direct textual influence, to give an answer to Pascal's fideism, both in his philosophy of religion and in his secular account of human nature and its instincts. If the thought of these two does indeed mesh in the way I have suggested, their writings give us the two supreme expressions of anti-rationalist thought in early modern times. Neither has been bettered, in my view, as an exemplar of the stance he represents. By comparison with Pascal, for example, Kierkegaard is turgid; by comparison with Hume, Kant is ludicrously professorial and Russell merely frivolous. If one compares the systems, it becomes, in my view, clearer and clearer that each has resources that enable him to answer, and also to explain, the other. For over and over, they are each telling the same tale, in a different tone of voice. How are we lesser thinkers to decide between them? 
My own view, for what it is worth, is that there is no way of doing so if we accept the starting point that they share: the belief that somehow we can discover the right stance to take towards our world by understanding our own natures and their needs. Pope took this from Pascal and put it into heroic couplets; but stating it in heroic couplets does not turn it into a deeper insight. The very deadlock that Pascal and Hume represent, when we place one against the other, suggests that it may be mistaken to suppose that we can understand ourselves and our needs without knowing the answers to some of those hard questions about what sort of cosmos we inhabit. If there is a God who wants to reach us, then our needs are likely to be rather different from what they would be if there is not. We seem to need to know whether or not this is so before we know what our real natures are.

But what about all those Sceptical arguments that suggest questions of this vast nature are beyond us? All I can say is that if they are indeed beyond us, then we are also incapable of understanding ourselves very fully. Scepticism does lead to indecision, because it stands in the way of self-knowledge. ${ }^{27}$

\section{TERENCE PENELHUM}

University of Calgary

\section{Notes}

1 David Hume, Enquiry Concerning Human Understanding, in Enquiries Concerning Human Understanding and Concerning the Principles of Morals, ed. L. A. Selby-Bigge, 3rd ed., rev. P.H.Nidditch (Oxford: Clarendon, 1975) 346; hereafter cited parenthetically as $E U$.

2 'In short, the supernatural cure was so uncontestable, that it saved, for a time, that famous monastery from the ruin with which it was threatened by the Jesuits. Had it been a cheat, it had certainly been detected by such sagacious and powerful antagonists, and must have hastened the ruin of the contrivers. Our divines, who can build up a formidable castle from such despicable materials; what a prodigious fabric could they have reared from these and many other circumstances, which I have not mentioned! How often would the names of Pascal, Racine, Arnauld, Nicole, have resounded in our ears? But if they be wise, they had better adopt the miracle, as being more worth, a thousand times, than all the rest of their collection. Besides, it may serve very much to their purpose. For that miracle was really performed by the touch of an authentic holy prickle of the holy thorn, which composed the holy crown, which, \&c.' (EU 346).

3 See Antoine Arnauld et Pierre Nicole, La Logique, ou l'Art de Penser, ed. Pierre Clair et François Girbal (Paris: PUF, 1965) 335-51; English version, The Arts of Thinking, ed. James Dickoff and Patricia James, fwd. Charles Hendel 
(Indianapolis: Bobbs-Merrill, 1964) 337-54. See also Peter Jones, Hume's Sentiments: Their Ciceronian and French Context (Edinburgh: Edinburgh UP, 1982) 44-76. I am indebted also to Alasdair MacIntyre, 'Hume, Testimony to Miracles, the Order of Nature and Jansenism,' forthcoming in Faith, Scepticism and Personal Identity, ed. Hugo Meynell and J. J. MacIntosh (Calgary: U of Calgary P); this essay also deals with some of the parallels between Hume and Pascal that I explore below.

4 Enquiry Concerning the Principles of Morals, Enquiries 343 (hereafter cited parenthetically as $E M)$.

5 On this theme, see particularly Hume's The Natural History of Religion, ed. H.E.Root (London: Adam and Charles Black, 1956); the relevant sections are those in which Hume compares polytheism and monotheism, to the latter's disadvantage (VI-XIII).

6 Voltaire, Lettres philosophiques; ou Lettres anglaises, ed. Raymond Naves (Paris: Garnier, 1956) 141; for a discussion of Voltaire's attack on Pascal, see Mina Waterman, Voltaire, Pascal, and Human Destiny (1942; New York: Octagon, 1970).

7 This comment comes from the 1777 remarks on the Pensées, but they summarise perfectly the patronising judgments of the earlier set.

8 See Jones 198n. It is interesting to note that Hume's negative comments on Pascal in the Enquiry drew fire from a Scottish source. George Anderson took exception to them in an anonymous volume entitled An Estimate of the Profit and Loss of Religion (Edinburgh, 1753). In the chapter 'Of the Personal Advantages and Disadvantages of Religion,' Anderson insists that natural religion teaches the life to come is indeed of more consequence than this, but that this does not detract from its value as a source of moral virtue; and adds the comment that Hume's own analysis of virtue as what leads to approbation is one that should lead him to ascribe it to Pascal because of his spiritual achievements. Anderson's attacks on Hume were among the causes of the unsuccessful attempts to have him formally censured by the General Assembly of the Church of Scotland in 1755 and 1756. See E.C. Mossner, Life of David Hume (Edinburgh: Nelson, 1954), ch. 25.

9 This is documented in his letter to an unnamed physician, The Letters of David Hume, ed. J.Y.T. Greig, 2 vols. (Oxford: Clarendon, 1932) 1: 12-18; see also Mossner, ch. 7.

10 A Treatise of Human Nature, ed. L.A.Selby-Bigge, 2nd ed., rev. P.H. Nidditch (Oxford: Clarendon, 1978) 1.4.7, 264.

11 Pensées 68/205. The first number is the one given the fragment in the Lafuma ordering, and the second is the number in the Brunschvicg ordering; hereafter cited parenthetically. I quote from Pascal: Oeuvres Complètes, ed. Henri Gouhier (Paris: du Seuil, 1963).

12 This fragment appears in the Port-Royal edition of the Pensées at XXI.1; Port-Royal numbers subsequently cited parenthetically.

13 Dialogues concerning Natural Religion, ed. Norman Kemp Smith (Indianapolis: Bobbs-Merrill, 1980) 133.

14 See here John Barker, Strange Contrarieties: Pascal in England during the Age of Reason (Montreal: McGill-Queen's UP, 1975).

15 The authoritative study of this is Mara Vamos, 'Pascal's Pensées and the Enlightenment: The Roots of a Misunderstanding,' Studies on Voltaire and the Eighteenth Century 97 (1972): 7-145. 
16 This is recognised and developed in Denzil Patrick, Pascal and Kierkegaard, 2 vols. (London: Luuterworth, 1947).

17 In what follows, I make no attempt to do more than isolate some themes that appear in important fragments. Any general account of the psychology and epistemology of the Pensées would have to deal with matters there is no space for here; in particular, the doctrine of the Three Orders. For expositions of this, see, for example, J.H. Broome, Pascal (New York: Barnes and Noble, 1966) and Roger Hazelton, Blaise Pascal: The Genius of His Thought (Philadelphia: Westminster, 1974).

18 See also 419/419, 126/93 (P-R XXV.15), 698/119, 663/121.

19 Most important here is the role given the imagination in the formation of our belief in the reality of the external world (see Treatise 1.4.2).

20 On vanities, or forms of self-inflation, see 627/150 (P-R XXXIV.5), 597-455 (P-R XXIX.18), 668/457, 978/100. On diversions, see 136/139 (P-R XXVI. 1,2,3), 137/142 (P-R XXVI.1), 138/166 (P-R XXXI.3), 139/143 (P-R XXVI.2), etc.

21 Hume actually pronounces this verdict on Berkeley in a passage where he claims Berkeley's arguments lead to sceptical conclusions (see EU 155n).

22 The English is from Alban Krailsheimer, trans., Pensées (Harmondsworth: Penguin, 1966) 62.

23 I have attempted to deal at length with the whole issue of the relationship between scepticism and fideism in my book God and Skepticism (Dordrecht: Reidel, 1983); I discuss Pascal in chapters 4 and 5, Hume in chapter 6.

24 Compare the famous recorded remark about Descartes: 'Je ne suis pardonner à Descartes: il voudrait bien, dans toute la philosophie, se pouvoir passer de Dieu; mais il n'a pu s'empècher de lui donner une chiquenaude pour mettre le monde en mouvement; après cela, il n'a plus faire de Dieu' (Oeuvres Complètes 640).

25 Philo in Part IX of the Dialogues calls this the most likely moral condition of the deity or deities responsible for the world, given the facts of evil (212).

26 The first two identifications are by E.C.Mossner, the third by Anders Jeffner. For the former see 'The Enigma of Hume,' Mind 45 (1936): 334-49; for the latter, Butler and Hume on Religion (Stockholm: Diakonistyrelsens, 1966).

27 I am grateful to the Canadian Society for Eighteenth-Century Studies for the opportunity to present the arguments in this essay to a plenary session of their congress at the University of Calgary on October 17, 1991. I also had the opportunity to present them to the Royal Society of Edinburgh on March 18, 1992, during a lecture and research tour sponsored jointly by the Royal Society of Canada and the British Academy. I wish to record my gratitude for that occasion, and for the most rewarding visit of which it was a part. 